\title{
Determination of Trace Amounts of Copper(II) by Using Catalytic Redox Reaction between Methylene Blue and Ascorbic Acid
}

\author{
M. Nasiruddin KHAN ${ }^{\dagger}$ and Anila SARWAR \\ Department of Chemistry, University of Karachi, Karachi-75270, Pakistan
}

\begin{abstract}
A sensitive and selective kinetic-spectrophotometric method is proposed for the determination of $\mu \mathrm{g} \mathrm{mL}^{-1}$ amounts of $\mathrm{Cu}^{2+}$ based on its catalytic effect on the oxidation of L-ascorbic acid by Methylene Blue in a strongly acidic medium. The reaction is monitored spectrophotometrically by measuring the decrease in color intensity of Methylene Blue at $665 \mathrm{~nm}$. The analysis of $\mathrm{Cu}^{2+}$ ion is performed by a fixed-time method. At a given time of 2 min at $\mathrm{pH} 2.20$ and $32^{\circ} \mathrm{C}$, the detection limit is $10 \mathrm{ng} \mathrm{mL}^{-1}$ and the relative standard deviation for $0.4 \mu \mathrm{g} \mathrm{mL}^{-1} \mathrm{Cu}^{2+}$ is $3.60 \%(n=6)$. The method is free from most of the interferences and the effect of diverse ions on the determination of $\mathrm{Cu}^{2+}$ is also reported. The proposed method is virtually specific to copper and has been satisfactorily applied to its determination in electric copper wire samples and pharmaceutical products. Results were also verified by the atomic absorption spectrometry technique (AAS).
\end{abstract}

(Received January 29, 2001; Accepted June 20, 2001)

\section{Introduction}

The physiological role of copper as a trace element is well established. It is important to carry out the proper functioning of different metalloenzymes, such as ascorbic oxidase (oxidation of ascorbic acid). Evidence has been presented that at low levels copper is an essential element in the diet, whereas at higher concentrations it is toxic. Because of its toxicity and cumulative effect in the body, copper presents a health problem when it occurs in food or water, even in minute amounts.

A number of sensitive analytical methods are available for the determination of copper. Some of the most commonly used methods are spectrophotometric, ${ }^{1-3}$ fluorometric, ${ }^{4}$ thermometric, ${ }^{5}$ potentiometric, ${ }^{6}$ biamperometric ${ }^{7}$ and flowinjection determination ${ }^{8}$ methods.

Catalytic kinetic methods ${ }^{9}$ are an attractive alternative for the determination of trace amounts of copper. Such methods have the general advantage of combining high sensitivity with relatively simple procedures and apparatus. There are many kinetic methods for the determination of $\mathrm{Cu}^{2+}$ at trace levels based on the catalytic effect of its ion on various inorganic and organic indicator reactions. ${ }^{10-12}$ However, few of them have been used for the determination of copper in real samples, or samples of analytical interest. The chief shortcoming of a kinetic catalytic determination of copper is that in most cases highly sensitive methods are poorly selective, or vice versa. Hence, the development of more sensitive and selective catalytic methods for the kinetic determination of copper is still sought.

Our work enhanced the scope of kinetic studies based on the copper(II) catalyzed oxidation of ascorbic acid by Methylene

\footnotetext{
$\dagger$ To whom correspondence should be addressed.

E-mail: nkhan210@yahoo.co.uk
}

Blue in strongly acidic media. The system forms the basis for an assay relying on specrophotometric measurements at the wavelength of maximum absorption of the oxidation product of ascorbic acid. The proposed method permits the determination of $\mathrm{Cu}^{2+}$ at trace levels in different samples of analytical interest.

\section{Experimental}

\section{Reagents and chemicals}

L-Ascorbic acid $\left(\mathrm{H}_{2} \mathrm{~A}\right)$ was of BDH AnalR grade and its solution was always freshly prepared. A buffer solution of citric acid-disodium hydrogenphosphate was used as a solvent. Stock solutions of Methylene Blue (M.B.) $\left(5 \times 10^{-5} \mathrm{~mol} \mathrm{~L}^{-1}\right)$ and ascorbic acid $\left(5 \times 10^{-3} \mathrm{~mol} \mathrm{~L}^{-1}\right)$ were prepared in a buffer solution of $\mathrm{pH} 2.20$.

An assay solution of $1 \mathrm{~g} \mathrm{~mL}^{-1}$ of copper wire was prepared by dissolving $1.000 \mathrm{~g}$ copper foil (99.99\%) in nitric acid (1:1) and heated to expel nitrogen oxide, then diluted with distilled water.

Stress Tabs (manufactured by Cyanamid Pakistan Ltd.,) and Theragran Stress (manufactured by Bristol-Myers SQUIB Pakistan Ltd.,) tablets were purchased from local markets. First, ten Stress Tabs were weighed and pulverized. About 100 mg of tablet powder was accurately weighed and transferred to a $100 \mathrm{~mL}$ volumetric flask, which already contained a $50 \mathrm{~mL}$ buffer solution of $\mathrm{pH} 2.20$. The mixture was sonicated for 5 $\mathrm{min}$ at room temperature and centrifuged for $10 \mathrm{~min}$ at 3500 rpm. Diluted solutions were used to determine the copper content in the drug.

The same procedure was adopted to prepare the assay of a Theragran Stress tablet.

\section{Equipment}

A temperature-controlled UV-visible spectrophotometer (160-

A Shimadzu) was used for an absorbance measurement. The 


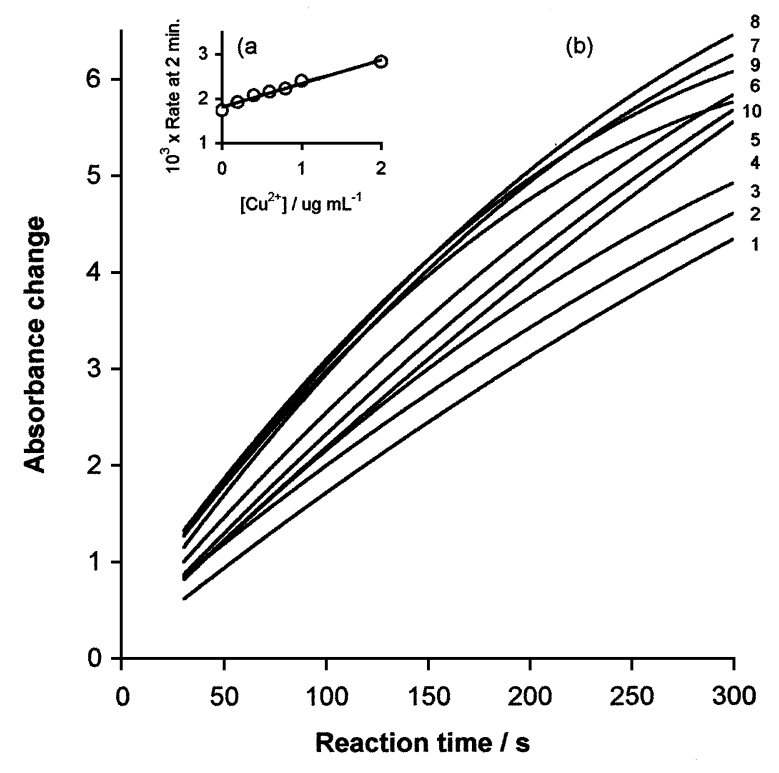

Fig. 1 Catalytic effect of $\left[\mathrm{Cu}^{2+}\right]$ on the oxidation of ascorbic acid by Methylene Blue. (a) Absorbance change vs. time plot: (1) blank (uncatalyzed reaction). $\left[\mathrm{Cu}^{2+}\right] / \mu \mathrm{g} \mathrm{mL}^{-1}$ : (2) 0.2 (3) 0.4 (4) 0.6 (5) 0.8 (6) 1.0 (7) 2.0 (8) 3.0 (9) 4.0 (10) 5.0. All other conditions are described under procedure. (b) The inset provides details for the rate vs. $\left[\mathrm{Cu}^{2+}\right]$ plot.

$\mathrm{pH}$ was measured with a digital Orion $710 \mathrm{pH}$-meter $( \pm 0.01$ $\mathrm{pH})$. The temperature $\left( \pm 0.1^{\circ} \mathrm{C}\right)$ was maintained in the reaction cell with a circulating water bath. In a $10 \mathrm{~mL}$ volumetric flask, $3 \mathrm{~mL}$ of $5 \times 10^{-3} \mathrm{~mol} \mathrm{~L}^{-1}$ ascorbic acid and an appropriate amount of $\mathrm{Cu}^{2+}$ standard solution were placed and kept in a water bath $\left(32^{\circ} \mathrm{C}\right)$ for $3 \mathrm{~min}$. Finally, a $2.0 \mathrm{~mL}$ volume of $5 \times$ $10^{-3} \mathrm{~mol} \mathrm{~L}^{-1}$ Methylene Blue was added to the same flask; 2.0 $\mathrm{mL}$ of the reaction mixture was transferred to a spectrophotometric cell and the variation of absorbance vs. time was recorded immediately. The absorbance was measured at $665 \mathrm{~nm}$ against a buffer solution.

\section{Results and Discussion}

There are several methods, such as fixed-time, fixedconcentration, initial-rate and rate-constant methods, for measuring the catalytic species. In this work we checked three methods:

1. The initial rate was plotted against $\left[\mathrm{Cu}^{2+}\right]$. The resulting calibration curve was linear over the range $0.2-1.0 \mu \mathrm{g} \mathrm{mL}^{-1}$ and the relative standard deviation (r.s.d.) was $3.8 \%$.

2. Figure 1a shows that the difference in the absorbance of a blank $\left(A_{0}\right)$ and a sample $(A)$ increased as the reaction time increased. The most suitable reaction time was $2 \mathrm{~min}$ after the addition of Methylene Blue, based on its correlation coefficient. A calibration curve was obtained by plotting the instantaneous rate against the $\mathrm{Cu}^{2+}$ concentrations. The curve was linear over

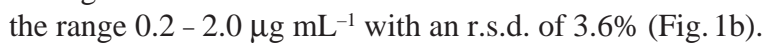

3 . In the fixed-concentration method the time needed to decrease a preset absorbance $(0.250)$ was taken as a basis. The determination range for copper between $0.2-0.8 \mu \mathrm{g} \mathrm{mL} \mathrm{m}^{-1}$ was accomplished with an r.s.d. of $6.3 \%$.

The fixed-time method was selected on the basis of its wider determination range and smaller r.s.d. compared to the other two.
Table 1 Correlation coefficients for the calibration curves at different reaction times after the addition of Methylene Blue

\begin{tabular}{cc}
\hline Reaction time/min & Regression coefficient $(r)$ \\
\hline 0.5 & 0.984 \\
1.0 & 0.987 \\
1.5 & 0.988 \\
2.0 & 0.999 \\
2.5 & 0.994 \\
3.0 & 0.983 \\
3.5 & 0.980 \\
4.0 & 0.974 \\
4.5 & 0.973 \\
5.0 & 0.971 \\
\hline
\end{tabular}

The influence of different parameters on the reaction rate was studied to establish the best reaction conditions and maximum sensitivity.

The initial concentrations of $\mathrm{H}_{2} \mathrm{~A}$ in the range of $(0.5$ to 3.0$) \times$ $10^{-2} \mathrm{~mol} \mathrm{~L}^{-1}$ were used to study the influence of $\left[\mathrm{H}_{2} \mathrm{~A}\right]$ with fixed $1.0 \times 10^{-5} \mathrm{~mol} \mathrm{~L}^{-1}$ Methylene Blue. The pseudo first-order rate constant increases with increasing $\left[\mathrm{H}_{2} \mathrm{~A}\right]_{\mathrm{t}}$. A plot of $k_{\mathrm{obs}} v s$. $\left[\mathrm{H}_{2} \mathrm{~A}\right]_{\mathrm{t}}$ was linear with a small intercept. This result implies that the reaction is first order with respect to $\left[\mathrm{H}_{2} \mathrm{~A}\right]_{\mathrm{t}}$. The plot of $k_{\mathrm{obs}}$ $v s$. Methylene Blue concentration ranging from (0.5 to 2.0$) \times$ $10^{-5} \mathrm{~mol} \mathrm{~L}^{-1}$ shows a linear relationship between $k_{\mathrm{obs}}$ and [M.B.] This fact reveals a first-order dependence in the oxidant as well.

An overall second-order rate equation will be expressed in the form

$$
-\mathrm{d}[\mathrm{M} . \mathrm{B} .] / \mathrm{d} t=k_{\mathrm{obs}}[\mathrm{M} . \mathrm{B} .]=k_{2}\left[\mathrm{H}_{2} \mathrm{~A}\right]_{\mathrm{t}}[\mathrm{M} . \mathrm{B} .] \text {. }
$$

Here, $k_{2}$ is the second-order rate constant; $\left[\mathrm{H}_{2} \mathrm{~A}\right]_{\mathrm{t}}$ indicates the total concentration of all forms of $\mathrm{L}$-ascorbic acid, and can be set as $\left[\mathrm{H}_{2} \mathrm{~A}\right]+\left[\mathrm{HA}^{-}\right]$at the working $\mathrm{pH}$.

The experimental results showed that the blank and catalytic reactions could proceed only in strongly acidic media $(\mathrm{pH}<$ 3.00). Therefore a $\mathrm{pH}$ of 2.20 was selected for this work.

The influence of the temperature was studied in a range 20 $40^{\circ} \mathrm{C}$. A temperature of $32 \pm 0.2^{\circ} \mathrm{C}$ was selected for better sensitivity and a lower detection limit.

The rate equation of the catalyzed reaction is

$$
\text { Rate }=-\mathrm{d}[\mathrm{M} . \mathrm{B} .] / \mathrm{d} t=k\left[\mathrm{Cu}^{2+}\right][\mathrm{M} . \mathrm{B} .]^{m}\left[\mathrm{H}_{2} \mathrm{~A}\right]^{n},
$$

where $k$ is the rate constant. By integrating Eq. (1) and incorporating Beer's law, we obtain the final expression under a fixed initial concentration of [M.B.] and $\left[\mathrm{H}_{2} \mathrm{~A}\right]$,

$$
\ln \left(A_{0} / A\right)=k^{\prime}\left[\mathrm{Cu}^{2+}\right]_{t},
$$

where $t$ is the reaction time.

Rate vs. $\left[\mathrm{Cu}^{2+}\right]$ linear graphs were obtained for solutions containing $0.1-1.0 \mu \mathrm{g} \mathrm{mL}^{-1} \mathrm{Cu}^{2+}$ with the regression equation $v=3 \times 10^{-4}\left[\mathrm{Cu}^{2+}\right]+0.0005$ with $r=0.9992$. The accuracy and precision for this analysis of six replicate measurements with various concentrations of $\mathrm{Cu}^{2+}$ are given in Table 2 .

The detection limit, calculated as the value corresponding to three-times the standard deviation of the blank (uncatalyzed reaction), is $10 \mathrm{ng} \mathrm{mL}^{-1}$. The relative standard deviation of six replicate determinations is $3.6 \%$ for $0.4 \mu \mathrm{g} \mathrm{mL}^{-1}$.

The possible potential interference of 25 foreign cations and anions in the solution was examined. Solutions of copper and 
Table 2 Accuracy and precision obtained by the recommended procedure

\begin{tabular}{ccc}
\hline $\begin{array}{c}\text { Amount of } \mathrm{Cu}^{2+} \text { present/ } \\
\mu \mathrm{g} \mathrm{mL} \mathrm{mL}^{-1}\end{array}$ & $\begin{array}{c}\text { Relative error of } \\
\mathrm{Cu}^{2+} \text { found, } \%\end{array}$ & $\begin{array}{c}\text { Relative standard } \\
\text { deviation }(n=5), \%\end{array}$ \\
\hline 0.2 & -2.3 & 0.67 \\
0.4 & +2.2 & 0.52 \\
0.6 & +1.9 & 0.47 \\
0.8 & +0.9 & 0.21 \\
\hline
\end{tabular}

Table 3 Selectivity achieved in the kinetic determination of $0.4 \mu \mathrm{g} \mathrm{mL}^{-1}$ of copper

\begin{tabular}{lc}
\hline \multicolumn{1}{c}{ Ions tested } & Tolerated ratio \\
\hline $\mathrm{SO}_{4}^{2-}, \mathrm{NO}_{3}^{-}$ & 3000 \\
$\mathrm{~Pb}^{2+}, \mathrm{Ni}^{2+}, \mathrm{Zn}^{2+}, \mathrm{Mg}^{2+}, \mathrm{Tl}^{+}, \mathrm{Ca}^{2+}, \mathrm{K}^{+}, \mathrm{Na}^{+}, \mathrm{Co}^{2+}, \mathrm{Br}^{-}$, & 1000 \\
$\mathrm{HCO}_{3}^{-}, \mathrm{F}^{-}, \mathrm{S}_{2} \mathrm{O}_{3}^{2-}, \mathrm{HCOO}^{-}, \mathrm{PO}_{4}{ }^{3-}$ & \\
$\mathrm{NH}_{4}^{+}$ & 200 \\
\hline
\end{tabular}

each ion tested were mixed to obtain samples containing $1 \mu \mathrm{g}$ $\mathrm{mL}^{-1}$ of $\mathrm{Cu}^{2+}$ and up to $3000 \mu \mathrm{g} \mathrm{mL}-1$ of the foreign ion. The maximum amount of a substance causing an error of less than $5 \%$ in the determination of $1 \mu \mathrm{g} \mathrm{mL}^{-1} \mathrm{Cu}^{2+}$ was taken as the tolerance limit (Table 3). $\mathrm{Fe}^{3+}, \mathrm{Fe}^{2+}, \mathrm{V}^{5+}, \mathrm{Cl}^{-}$, and $\mathrm{Ag}^{+}$interfered in the reaction.

$\mathrm{Ce}^{3+}$ alone has no catalytic effect, but in the presence of $\mathrm{Cu}^{2+}$, after reaching the threshold level, it promotes the rate of copper catalyzed reaction significantly, whereas $0.4 \mu \mathrm{g} \mathrm{mL}^{-1} \mathrm{Mn}^{2+}$ and $\mathrm{Cr}^{6+}$ show $12 \%$ and $15 \%$ inhibition for $0.4 \mu \mathrm{g} \mathrm{mL} \mathrm{m}^{-1} \mathrm{Cu}^{2+}$ ion, respectively.

The proposed method was applied to an analysis of $\mathrm{Cu}^{2+}$ in two pharmaceutical products and three electric copper wire samples. The obtained results are summarized in Table 4. The proposed kinetic method is in good agreement and comparable in accuracy and precision with a reference method, i.e. atomic absorption spectrometry (AAS).

The method was also checked against synthetic samples with a known amount of $\mathrm{Cu}^{2+}$. The recovery of added $\mathrm{Cu}^{2+}$ was $92-$ 95\% (Table 4).

The data given in Tables 4 and 5 show good performance and selectivity of the proposed kinetic method for the determination of $\mathrm{Cu}^{2+}$ in a variety of samples with a significant advantage to determine copper rapidly in samples over a wider concentration range.

\section{Conclusion}

The kinetic method proposed for the determination of $\mathrm{Cu}^{2+}$ is a sensitive and selective method. It is comparable in accuracy and precision with the reference method and other procedures described in the cited reference.

The procedure is also suitable for the analysis of $\mathrm{Cu}^{2+}$ in pharmaceuticals, because there is no interference from the excipients normally found in the commercial preparations. In addition, its high sensitivity permits its use in the determination
Table 4 Determination of $\mathrm{Cu}^{2+}$ in pharmaceuticals and electric wire samples

\begin{tabular}{lcc}
\hline \multicolumn{1}{c}{ Sample } & $\begin{array}{c}\mathrm{Cu}^{2+} \text { content per tablet/mg } \\
\text { Reference method }\end{array}$ & $\begin{array}{c}\text { Proposed } \\
\text { method }^{\mathrm{a}}\end{array}$ \\
\hline Stress tabs & 2.84 & $2.53 \pm 0.11$ \\
Theragran stress & 3.05 & $2.89 \pm 0.15$ \\
Wire sample 1 & 0.477 & $0.51 \pm 0.07$ \\
Wire sample 2 & 0.50 & $0.52 \pm 0.04$ \\
Wire sample 3 & 0.52 & $0.54 \pm 0.05$ \\
\hline
\end{tabular}

a. Mean of five-determination \pm relative standard deviations.

Table 5 Determination of $\mathrm{Cu}^{2+}$ in synthetic samples

\begin{tabular}{ccccc}
\hline Sample & $\begin{array}{c}\text { Added/ } \\
\mu \mathrm{g} \mathrm{mL}^{-1}\end{array}$ & $\begin{array}{c}\text { Found/ } \\
\mu \mathrm{g} \mathrm{mL}^{-1}\end{array}$ & $\begin{array}{c}\text { Recovery, } \\
\%\end{array}$ & $\begin{array}{c}\text { Relative error, } \\
\%\end{array}$ \\
\hline 1 & 0.2 & 0.184 & 92.0 & -8.00 \\
2 & 0.2 & 0.189 & 94.5 & -5.50 \\
3 & 0.3 & 0.280 & 93.3 & -6.62 \\
\hline
\end{tabular}

Sample 1: $0.2 \mu \mathrm{g} \mathrm{mL}^{-1}$ of $\mathrm{Cu}^{2+}+10 \mu \mathrm{g} \mathrm{mL}^{-1}$ of $\mathrm{Zn}^{2+}$ and $\mathrm{Tl}^{+}$. Sample 2: $0.2 \mu \mathrm{g} \mathrm{mL}^{-1}$ of $\mathrm{Cu}^{2+}+10 \mu \mathrm{g} \mathrm{mL}^{-1}$ of $\mathrm{Zn}^{2+}, \mathrm{Tl}^{+}$and $\mathrm{Ni}^{2+}$. Sample 3: $0.3 \mu \mathrm{g} \mathrm{mL}^{-1}$ of $\mathrm{Cu}^{2+}+10 \mu \mathrm{g} \mathrm{mL}^{-1}$ of $\mathrm{Zn}^{2+}, \mathrm{Tl}^{+}, \mathrm{Ni}^{2+}$ and $\mathrm{Pb}^{2+}$.

of industrial copper products.

\section{Acknowledgements}

The authors are grateful to the Dean, Faculty of Science, University of Karachi, for financial support.

\section{References}

1. J. F. Van Staden and A. Botha, Talanta, 1999, 49, 1099.

2. S. Nohut, S. Karaboecek, S. Guener, and Y. Goek, J. Pharm. Biomed. Anal, 1999, 20, 309.

3. Y. Zhou and H. Jiang, Fenxi Ниахие, 1992, 20, 1228.

4. J. Medina-Escriche and P. Hernandez, Analyst [London], 1985, 110, 1457.

5. I. Bargallo, F. Borrull, V. Cerda, and J. Guasch, Thermochim. Acta, 1987, 117, 283.

6. H. P. Chen, Lihua Jianyan, Huaxue Fence, 1999, 35, 371.

7. L. Huang and H. Gao, Gaodeng Xuexiao Huaxue Xuebao, 1992, 13, 179.

8. N. Teshima, H. Katsumata, M. Kurihara, T. Sakai, and T. Kawashima, Talanta, 1999, 50, 41.

9. H. A. Mottola, "Kinetic Aspects of Analytical Chemistry", 1988, John Wiley and Sons, New York, Chichester, Brisbane, Toronto, Singapore, 37.

10. D. Perez-Bendito and M. Silva, "Kinetic Methods in Analytical Chemistry", 1988, Harwood, Chichester.

11. H. A. Mottola, D. Perez-Bendito, and H. B. Mark, Jr., Anal. Chem., 1988, 60, $181 \mathrm{R}$.

12. N. Pourreza and M. Behpour, Anal. Sci., 1998, 997. 